\title{
From Man of the Crowd to Cybernaut: Edgar Allan Poe's Transatlantic Journey-and Back.
}

Paul Jahshan

\section{(2) OpenEdition \\ Journals}

Electronic version

URL: https://journals.openedition.org/ejas/2293

DOI: $10.4000 /$ ejas. 2293

ISSN: 1991-9336

Publisher

European Association for American Studies

\section{Electronic reference}

Paul Jahshan, "From Man of the Crowd to Cybernaut: Edgar Allan Poe's Transatlantic Journey-and Back.", European journal of American studies [Online], 3-3| 2008, document 1, Online since 23 July 2008, connection on 08 July 2021. URL: http://journals.openedition.org/ejas/2293 ; DOI: https://doi.org/ 10.4000/ejas.2293

This text was automatically generated on 8 July 2021.

Creative Commons License 


\title{
From Man of the Crowd to Cybernaut: Edgar Allan Poe's Transatlantic Journey-and Back.
}

\author{
Paul Jahshan
}

The wild effects of the light enchained me to an examination of individual faces; and... it seemed that, in my then peculiar mental state, I could frequently read, even in that brief interval of a glance, the history of long years. (Poe 183) ${ }^{1}$

'This old man,' I said at length, 'is the type and the genius of deep crime. He refuses to be alone. He is the man of the crowd. It will be in vain to follow; for I shall learn no more of him, nor of his deeds...and perhaps it is but one of the great mercies of God that es lässt sich nicht lesen. (P 188)

Here a change in his demeanor became evident. He walked more slowly and with less object than before-more hesitatingly. He crossed and re-crossed the way repeatedly without apparent aim; and the press was still so thick, that, at every such movement, I was obliged to follow him closely. (P 184-85)

1 The three short passages above convey three characteristics in Edgar Allan Poe's fiction which have proved to be crucial elements in detective fiction from 1840, the date of publication of "The Man of the Crowd," until the present day, namely, the detective-asphysiognomist, the ontological quester, and the flâneur. I will show how these three constants crossed, as it were, the Atlantic, received from Europe renewed impetus in the shape of a postmodern sensibility, and then returned to the New World, powerfully shaping the American detective genre. There, modern and contemporary fiction, most notably that of Thomas Pynchon, Paul Auster, Don DeLillo, and E. L. Doctorow, on the one hand, and cyberpunk, on the other hand, picked up where Poe had left, added to it, and reached a culmination in the eventual decentering of Dupin's original position and the reclaiming of the flâneur as a new discursive strategy in detective fiction. The new, third-millennium detective has been endowed with Poesque visitations similar to those encountered, more than a century and a half earlier, by the narrator of "The Man of the Crowd," but later acquired a unique status made only possible by the transatlantic journey. 
2 It is a well-known fact that Poe created the detective story, and critics have been quick to associate the detective with the flâneur in Poe's fiction. Gerald Kennedy, in 1975, described "The Man of the Crowd" as having "long been one of Poe's most perplexing tales," where the protagonist, instead of fleeing his double, like in "William Wilson," in fact pursues him. To Kennedy "The Man of the Crowd" marks the beginning of Poe's "ratiocinative cycle," and the humorous "The Oblong Box," in 1844, marks its end. Kennedy, however, is just as dismissive about the end as he is about the beginning, and advises his readers to stay away from both, focussing instead on the more mature Dupin stories in between. Interestingly, Kennedy's problem with "The Man of the Crowd" is the narrator's inability to understand the rules of investigation later used by Dupin, and his self-delusion.

3 But it is precisely this consciously accepted failure by the story's narrator that has fueled renewed contemporary interest in Poe's investigative philosophy and firmly anchored his descendents in a long metaphysical tradition, culminating in postmodernism and beyond. The ontological problem raised by Poe in "The Man of the Crowd," his acknowledgment that it "will be vain to follow," that no more can be learned from the stranger stalking the streets in search of an identity amidst the crowd, was to develop later into the metaphysical, the postmodern, and finally the cybernaut investigator.

4 The flâneur, a creation of early nineteenth-century Paris, is a recurring element in Poe's tales, especially those termed "ratiocinative," and a major focus of interest since Charles Baudelaire, and later Walter Benjamin, popularized the study of this unique product of the densely populated urban space. Dana Brand's The Spectator and the City in Nineteenth-Century American Literature focussed on Poe's detective flâneur and on Walter Benjamin, and Keith Tester called the flâneur "a very obscure thing" (qtd in Werner 5). James Werner took up Benjamin's view in ascribing the rise of the detective to precisely the creation of the flâneur, writing:

The triumph of societal forces was putting the flâneur to use as detective [... ]The rise of the detective reflects society's uneasiness about the flâneur and its pressure to mitigate his elusiveness. (6)

Werner firmly links the flâneur with the detective in Poe's tales, putting flânerie at the "very heart" of his ratiocinative techniques, and calling "The Man of the Crowd" one of the "most successful instances of flânerie in Poe" (10). Contrary to what Kennedy and Brand believed, the narrator in "The Man of the Crowd" and Dupin are, to Werner, one, and the detective is best seen in Poe as he is engaged in the act of flânerie. Werner is also astute enough to maintain that the detective and flâneur in Poe make up for the uncanny ability to be "in the scene yet removed from it" (11), a crucial dichotomy as regards the investigative flânerie of the cybernaut.

6 The Poesque detective, ontological quester, and flâneur, have had to go through a transatlantic "pilgrimage" in order to acquire the much-needed elements which have made contemporary American detective fiction what it is today. Indeed, much ink (and now countless digital bytes) has been spilled over the question of Poe's influence on European literature and vice-versa. The pull to own Poe has been strong enough to warrant heated discussions on both sides of the Atlantic. As early as 1927, F. M. Darnall, in an article entitled "The Americanism of Edgar Allan Poe," attempted to show that the elements of Americanism, namely, idealism, romance, and individualism, are outstanding characteristics of Poe, despite opinion otherwise. In addition, Poe's 
imagery, to Darnall, is deeply rooted in American history, and harks back to the time of the Puritan Fathers. Conversely, John Matthew, in 1936, claimed that Poe was not only an influence on French literature, but was also deeply indebted to it to begin with. Marcel Françon, in 1945, explained Baudelaire's “déjà vu" feeling upon encountering Poe by claiming that Poe was initially influenced by French/European writers like Coleridge, Schelling, Novalis, Mme de Staël, and Balzac. More recently, Robert Shulman, in "The Artist in the Slammer," placed Poe with Hawthorne and Melville in the group of writers who saw America as a prison and looked across the Atlantic for fulfillment and recognition. Monika M. Elbert, in the opposite camp, was even more vocal when she said, in the context of "The Man of the Crowd," that:

There has been a French plot to purloin our American Poe. It is time to bring Poe back to American soil, to place him in the context of his time, as a representative American man of the mid-nineteenth century. (16)

The transatlantic battle to win Poe was, of course, initiated by translations of his tales into French as early as 1845 , with Baudelaire subsequently trying to contact Poe's first "secret translator," Amédée Pichot, for his original sources (Bandy). Such was the interest in Poe in France that Edith Philips, in 1927, went into the minute tracing of the use of French words and expressions in the American writer's tales, and Claire-Eliane Engel, in 1932, reported on the voluminous state of academic research on Poe in France. ${ }^{2}$ A decade later, Dudley R. Hutcherson summed up the heated discussion surrounding Poe's reputation in England and America a year after the writer's death until 1909, delineating the works of Poe's moral detractors and defenders. Joseph N. Riddel presented the ambivalence still existing about Poe and French literature, where, to some, the American writer is a pure French creation, whereas, to others, he invented symbolist poetics. Studies by Eleonore Zimmermann on Poe and Mallarmé, by Reino Virtanen on Poe and Valéry, and by James Lawler on Poe and the symbolists, are examples of the numerous research done on the American writer's influence on the French symbolists.

of course, Poe's reputation as the first detective story writer and his influence across the Atlantic are not restricted to France. Charles Dickens, R. L. Stevenson, Wilkie Collins, Sir Arthur Conan Doyle, E. C. Bentley, G. K. Chesterton, Dorothy Sayers, Agatha Christie, and others testify to the popularity of the genre. Robert Ashley, in 1951, traced Poe's influence on the British detective story, citing Collins as the link between Poe and Doyle. As with the French connection above, Poe's legacy to the British Isles has been adequately documented.

If Collins was the link between Poe and the English detective scene, it is undoubtedly Benjamin who united, with his studies of the flâneur in the Parisian arcades, Poe's theme of the crowd with that of the detective and paved the way for the fusion of the two into an existential questioning that would eventually lead to the postmodern detective. The flâneur, with Benjamin, is not only the dandy who slides among the city crowds, observing their features and trying to get at the bottom of their hidden motives; he is also, according to Rolf J. Goebel, the "personification of geographic dislocation, cultural transgression, and conceptual reconfiguration" (378). As such, the flâneur, envisioned-and, by the same token, re-created-by Benjamin, is an observer and an actor in the drama facing humanity at the dawn of the twentieth century, a drama which, as I will show, shows no sign of abating even as this humanity is being ushered into yet another era, that of digital information. 
10 The narrator-observer in Poe's "The Man of the Crowd," sitting behind the window of a café and recuperating after some illness, was safely situated in an interior which provided him with all the amenities of seclusion:

With a cigar in my mouth and a newspaper in my lap, I had been amusing myself for the greater part of the afternoon, now in poring over advertisements, now in observing the promiscuous company in the room, and now in peering through the smoky panes into the street. (P 179)

11 When the narrator first sees the old man and tries, in vain, to decipher his secret, he has to leave the interior, his position behind the window-as-screen and go outside, in the midst of the very crowd he had been observing:

Hurriedly putting on an overcoat, and seizing my hat and cane, I made my way into the street, and pushed through the crowd in the direction which I had seen him take; for he had already disappeared. (P 184)

12 The passage from the interior to the exterior is important to the dialectics of the detective as flâneur. Benjamin writes, in The Arcades Project:

The interior is not just the universe but also the étui of the private individual. To dwell means to leave traces. In the interior, these are accentuated [...] Enter the detective story, which pursues these traces. Poe [...] in his detective fiction, shows himself to be the first physiognomist of the domestic interior. (9)

13 Yet, it is when the narrator of "The Man of the Crowd" leaves and moves from the interior to the exterior that he gradually loses his composure and ultimately plunges into the unknowability of the crowd, of the exterior, of the unfathomable. Benjamin writes, quoting Baudelaire on Poe's story:

From behind the window of a café, a convalescent, contemplating the crowd with delight [...] Finally, he rushes into the crowd in search of an unknown person whose face, glimpsed momentarily, fascinated him. Curiosity has become a fatal, irresistible passion. (442)

Poe's foray into what will be, more than a century later, the common grounds of postmodernism, will not be repeated, and Dupin is seen to be much more at ease in interiors than in exteriors. As Peter Schmiedgen remarked, the city is "one of the loci of both hope and fear within modernity," and the café, to Benjamin, is the "partial crystallization out of the ever changing crowd" $(47,50)$. To the narrator of "The Man of the crowd," the exterior was just a screen to be gazed at, leisurely and safely, a spectacle which could be shut off at will. The tension between a detection of the interior as detective and a more real exchange in the exterior as flâneur is probably the central theme of the story. Benjamin states:

It is the gaze of the flâneur, whose way of life still conceals behind a mitigating nimbus the coming desolation of the big-city dweller [...] He [the flâneur] seeks refuge in the crowd. Early contributions to a physiognomics of the crowd are found in Engels and Poe. The crowd is the veil through which the familiar city beckons to the flâneur as phantasmagoria-now a landscape, now a room. (10)

Benjamin credited Poe with creating "a character who wanders the streets of capital cities [calling] him the Man of the Crowd" (96). The cityscape is an ambivalent space which both lures and repels, and it is precisely this space, so daunting to Poe in 1840 , which is taken up and exorcized in contemporary American detective fiction and in the treatment of cyberspace.

16 The advent of postmodernism will not only take up where Poe left in awe, but will also alter classical detective fiction forever, and what is known as the "Ellery Queen 
yardstick" for detective fiction, that is, a detective who detects, who is the story's protagonist, and who triumphs over the criminal (Ashley 48), will be severely challenged. That this change took place initially in France before leaving a trail in the rest of the world has been acknowledged by most historians of thought. François Cusset, in French Theory, admirably set out to trace the influence of Foucault, Derrida, Deleuze, and many others on the intellectual life of the United States. The influence is so pervasive that Cusset himself is puzzled by the extent of what he sees as an "invasion" (21). What this epochal moment effected has been the subject of countless studies; briefly put, one can mention the decentering of authorial voice, the undecidability of meaning, the deferred role of the critic, a re-evaluation of more than 2,000 years of western philosophy and the premium place it accorded to an ultimate Signified or Truth, and the realization that all interpretive practice, at all levels, is a kind of writing, and this writing itself a fictional construct. Indeed, William V. Spanos pointed out that if Poe and Doyle were presenting a comforting view of the universe, postmodern writers like Pynchon were experimenting with the anti-detective fiction, the antithesis of the positivistic universe with its totalitarian implications, and thus did their best to subvert the classical notions of plot. What became known as the "metaphysical" detective novel was the opposite of the classical ratiocinative tales started by Poe's Dupin and taken over by Doyle, and the new genre was characterized by its overt attempts at defeating the previously established "syllogistic order" (Cannon 46). As mentioned above in the context of the innovations of postmodernism, JoAnn Cannon writes that detection is a metaphor of all reading, and that it "dramatizes the operation performed by the reader of all texts" (46).

18 The classical detective's panoply, enriched with postmodernism's legacy of openendedness and reader empowerment, was also ready to embrace the newer version of the flâneur, the Deleuzian nomad moving in the smooth and rhizomatic spaces of the new urban landscape. In Mille Plateaux, Gilles Deleuze and Félix Guattari describe the contemporary nomad:

The nomad has a territory, he follows habitual paths, he goes from one point to another, he does not ignore points (water points, dwelling points, assembly points) ...The water point is there only to be left, and any point is a relay and exists only as relay [...] the nomad goes from one point to another only as consequence and necessity: in principle the points are to him relays in a trajectory. (471)

Like Poe's old man in "The Man of the Crowd," described as moving from one point in the crowd to another, the nomad-detective-flâneur is content to peregrinate from one event to another, leading behind him the reader, just as the old man did with the bemused and then irritated narrator. The difference is that the reader-turned-detective has learned to understand-and to enjoy-the seemingly meaningless meanderings of the text.

What is also interesting is that the dichotomy between the interior and the exterior, so acutely felt by Poe in "The Man of the Crowd," is placed by Deleuze and Guattari in a more definable rapport:

The nomad distributes himself in smooth space; he occupies, he lives, he holds this space, and it becomes his territorial principle. It is thus wrong to define the nomad by movement [...] of course the nomad moves, but he is sitting, he is never as much moving as when he is sitting (the galloping bedouin). (472) 
The narrator behind the café's window had to move out to pursue his investigation, but the reader moves with the narrative without moving, just as the cybernaut, in front of the computer screen, can travel the whole world of data without leaving his/her seat. Reading becomes nomadic and it is not enough anymore to discover, along with the writer-narrator-detective, multiple and open-ended meanings, but also to produce them (Briggs), and the reader becomes engaged in a Barthesian writerliness mirrored by the detective's own ramblings in the textual spaces of the city.

The movement from the classical, ratiocinative tales of Poe and Doyle, to the "aristocrat/gentlemanly" thriller of manners of Bentley, Christie and Sayers, to the "hard-boiled," realistic novels of Dashiell Hammett and Raymond Chandler, has been vividly painted, among others, by George Grella, Michael Holquist, and Carl D. Malmgren, and although a lot has been written on contemporary mystery writers like Pynchon, Auster, DeLillo, and Doctorow, the link to Poe's "Man of the Crowd" and to the transatlantic metamorphosis needs to be more firmly anchored. ${ }^{3}$

Kenneth Kupsch has found Poe overtones in Pynchon's 1961 novel V., and wrote that the "V" puzzle is answered in a way which opens up instead of closing the book, and that readers must be willing to do the legwork, like Stencil, the detective in the novel. More recently, Daniel Punday explored the Pynchon-Deleuze connection in a similar context. In the novel, a spy is carrying with him a secret which later becomes the rallying point of different characters whose stories meet. Pynchon's flâneur in the crowd is reminiscent of that in Poe's story:

He watched the tourists gaping at the Campanile; he watched dispassionately without effort, curiously without commitment [...] those four fat schoolmistresses whinnying softly to one another by the south portals of the Duomo, that fop in tweeds and clipped mustaches who came hastening by in fumes of lavender toward God knew what assignation; had they any notion of what inner magnitudes such control must draw on? (V. 184)

Four years later, with The Crying of Lot 49, Pynchon went deeper into the interaction between the crowd, the voyeuristic gaze, and the city. As Oedipa Maas tries to find the post-horn symbol, she goes through the realization that the city is offering itself to her gaze:

Oedipa played the voyeur and listener. Among her other encounters were a faciallydeformed welder, who cherished his ugliness; a child roaming the night who missed the death before birth as certain outcasts do the dear lulling blankness of the community; a Negro woman with an intricately-marbled scar along the baby-fat of one cheek. (Lot 49 85)

Oedipa's wanderings in the city leave her at the mercy of an unknown crowd she thought did not exist, and the realization is enough to transform her as deeply as the narrator of "The Man of the Crowd."

The metaphysical/postmodern detective was first clearly identified in Auster's 1985 New York Trilogy. As Steven E. Alford pointed out, Auster's characters in the Trilogy face the constant deferral of knowing themselves, an ontological problem reflected in the impossibility of solving, satisfactorily, all detective investigations. In true Poesque vein, Auster's detectives are confronted with the "es lässt sich nicht lesen" ("it does not let itself be read") of "The Man of the Crowd." To William G. Little, the "interminable wandering," "re-tracing," and "perpetual crossing" done by the protagonists of City of Glass, the first story in the Trilogy, "lead to no final illumination, no climactic discovery" (133-34). 
27 Not all critics, however, have seen the Poe influence in that way, preferring to see Dupin as the only embodiment of the detective. John Zilcosky, for example, sees Auster as simply overturning the classical rules of detective fiction set out by Dupin and disregards the flâneur-quester side. Yet, New York, to Auster's detective, Quinn, is a Benjaminesque and Deleuzian labyrinth:

The world was outside of him, around him, before him, and the speed with which it kept changing made it impossible for him to dwell on any one thing for very long [...] By wandering aimlessly, all places became equal, and it no longer mattered where he was. (Trilogy 4)

Quinn's double is a character taken from Poe, William Wilson, his pseudonym for writing detective stories, and the mind-boggling shuffling and interchanging taking place in the Trilogy between real author (Auster), narrator (Quinn), writer (William Wilson), and persona (Auster, twice), answers what Quinn already knows when he says: "In effect, the writer and the detective are interchangeable" (Trilogy 9). Quinn is a true nomad writer and reader, moving from one story to another: "What interested him about the stories he wrote was not their relation to the world but their relation to other stories" (8). In a passage almost identical to Poe's "The Man of the Crowd," Quinn searches the crowd in a train station for Peter Stillman, the old man supposedly come back to New York to kill his son, also named Peter Stillman:

Soon the people were surging around him [...] Quinn watched them all, anchored to his spot, as if his whole being had been exiled to his eyes [...] he rapidly shifted his expectations with each new face, as if the accumulation of old men was heralding the imminent arrival of Stillman himself. For one brief instant Quinn thought, "So this is what detective work is like." But other than that he thought nothing. (Trilogy 66)

Almost ten years later, Auster's Oracle Night evinced this same preoccupation. The narrator, a writer who writes about writers is, like the narrator of "The Man of the Crowd," recovering from a long illness and, as the story starts, is out among the crowds:

I had lived in New York all my life, but I didn't understand the streets and crowds anymore, and every time I went out on one of my little excursions, I felt like a man who had lost his way in a foreign city [...] I drifted along like a spectator in someone else's dream, watching the world as it chugged through its paces and marveling at how I had once been like the people around me. (1-2)

30 The unknown also lurks in DeLillo's Mao II, where the narrator vividly describes the fascination found in observing and detecting individual traits in the crowd. The Poesque and Deleuzian "bedouin" allusions are obvious:

There are still more couples coming out of the runway and folding into the crowd, although "crowd" is not the right word...there are curiosity seekers scattered about, ordinary slouchers and loiterers, others deeper in the mystery, dark-eyed and separate, secretly alert, people who seem to be wearing everything they own, layered and mounded in garments with missing parts, city nomads more strange [...] than herdsmen in the Sahel. (4)

The reporter's lens serves, in Mao II, the same function as the window in "The Man of the Crowd," shielding yet revealing at the same time:

Crowds [...] People trudging along wide streets, pushing carts or riding bikes, crowd after crowd in the long lens of the camera so they seem even closer together than they really are, totally jampacked...Totally calm in the long lens, crowd on top of crowd. (70) 
lo goes a step further in Cosmopolis and has his protagonist, the "multi-billionaire" Eric Packer, move around Manhattan in an armored car, where he conducts actual meetings, listens to reports from his counselors, and even has a medical checkup. As Packer begins his day, he is connected to a bevy of data-displaying units, ranging from the stock exchange rates to TV news, to surveillance cameras placed in strategic places. As a futuristic nomad, Packer is moving around the city without moving, his mobile office going wherever he is. Yet Packer's isolation, like that of his staff, will in the course of the novel lead him to reconsider his priorities, until the final confrontation which will take place in "real life." In the meantime, Packer is mesmerized by the power he has, from the cameras placed in his car or from behind his coated windows, of watching others watching crowds:

These were scenes that normally roused him, the great rapacious flow, where the physical will of the city, the ego fevers, the assertions of industry, commerce and crowds shape every anecdotal moment. (41)

world as seen from behind the screen is a source of pleasure and power but, as DeLillo shows at the end, also provides a false sense of security. As the plot unfolds, however, Packer intermittently crosses from his interior to the exterior and mingles with others, albeit sporadically. Near the end of the novel, Packer comes across a film shooting taking place in the middle of the street with "three hundred naked people sprawled in the street" (Cosmopolis 172). It is clear that Packer's initial shock at seeing so much exposed flesh is due to a violation of the machine-like nature of the interior, the false safety of the window/screen/monitor, and an invitation to step out, like the narrator of "The Man of the Crowd," onto the exterior spaces, an invitation he decides to accept:

It tore his mind apart, trying to see them here and real, independent of the image on a screen in Oslo or Caracas [...] He wanted to set himself in the middle of the intersection, among the old with their raised veins and body blotches and next to the dwarf with a bump on his head [...] He was one of them. (176)

It is this Benjaminesque mapping of life over the Poesque city streets that also informs Doctorow's City of God. The streets are not empty, however, and the narrator, in this novel featuring a priest-detective with a degree in divinity-detective, "D.D.," pauses to reflect on the metaphysical nature of the crowd and the need to walk and immerse oneself among them, like the old man in "The Man of the Crowd":

But I can stop on any corner at the intersection of two busy streets, and before me are thousands of lives headed in all four directions, uptown downtown east and west, on foot, on bikes, on in-line skates, in buses, strollers, cars, trucks, with the subway rumble underneath my feet [...] For all the wariness or indifference with which we negotiate our public spaces, we rely on the masses around us to delineate ourselves. (11)

Doctorow describes crowds as "the most spectacular phenomenon in the unnatural world" because he felt, like DeLillo above, and like Poe a century and a half earlier, that the big city, a construct of stone, steel, and glass, is set, maybe indefinitely, to compete with the flesh. What cannot let itself be read, as in Poe's phrase, is the crowd's ultimate fleshiness, the undecidability and unknowingness of the human mind. Mapped onto the city-scape, the detective/reader has to leave the prison of the interior and stalk, flâneur-like, the uncertain reaches of the human text.

It will come as no surprise, then, that with the advent of the "new technologies" and their attending concepts of simulation and virtual reality, the dichotomy between the 
interior and the exterior, so prevalent in Poe, Benjamin, and the postmodern detective, becomes more acutely felt. As Lawrence Frank said in the context of Poe's detective tales, the appearance of new genres takes place when historical circumstances need it. Likewise, the appearance of the cyber-detective-flâneur has followed the development of the "new technologies," and its best representation has been cyberpunk. Steffen Hantke wrote that Poe's "close association with the beginnings of science fiction alone secures him a place in the genealogy of steampunk" (247), and Paul C. Grimstad not only reiterated Poe's position as the inventor of the analytical detective story, but also as the writer who laid the groundwork for cyberpunk writers like William Gibson and Neal Stephenson, also tracing Gibson's debt to Pynchon's The Crying of Lot 49. Others, like Randy Schroeder, have dubbed Pynchon the "grand-daddy" of Stephenson's Snow Crash (89). The link between cyberpunk and postmodernism, particularly the French flavor of it, has been set by Cusset:

The science fiction genre itself has made way to French theory [...] With the pioneer of the genre, William Gibson-who invented in 1982 the term "cyberspace"-they are many famous novelists who associate themselves with French authors. Often quoting Deleuze or Baudrillard in their interviews, they are read by their critics, or by their learned fans, through the prism of the simulacrum or, as metaphor of the Net, of the "body without organs" [...] We are here indeed in the realm of theoretical science fiction. (269)

Gibson's landmark novel, Neuromancer, set the tone in 1984 for the new genre of cyberpunk and its close cousin, steampunk. Gibson's characters, in what will be a trilogy including Count Zero (1986) and Mona Lisa Overdrive (1988), move in a world described by Jason Haslam as having a "retro-future feel," where "space-age computer technology co-exists with grime, filth, and [...] an all-encompassing urban decay, characterized by Gibson as "The Sprawl"' (Haslam 93). The futuristic city is crowded, on one level, with people and, on another level, with the exchange of data making up the daily business of mega-companies, a traffic of flesh and information. The city crowds, as in Poe's story, are made of shoppers who stroll in search of goods to buy: "Summer in the Sprawl, the mall crowds swaying like windblown grass, a field of flesh shot through with sudden eddies of need and gratification" (Gibson 60).

As Werner remarked, the danger for the flâneur is "of being reduced to the status of passive window-shopper or consumer" (6), obviously referring to Benjamin's sad observation, in the Arcades Project, that the flâneur's "final ambit is the department store" (448). Yet, when Case, Gibson's protagonist, "jacks in" to his holodeck and plunges into cyberspace, he is stepping into a space which is neither the interior nor the exterior of everyday reality. His trip transports him into a virtual space which combines both the observer and the observed, a "consensual hallucination experienced daily by billions of legitimate operators, in every nation" (Gibson 67). Benjamin, in the Arcades, called Poe's interior/exterior dichotomy the "dialectic of flânerie":

[O]n one side, the man who feels himself viewed by all and sundry as a true suspect and, on the other side, the man who is utterly undiscoverable, the hidden man. Presumably, it is this dialectic that is developed in 'The Man of the Crowd"' (420).

Stephenson takes the simulatory nature of the crowd a step further in Snow Crash, where he envisions cyberspace as a huge virtual construct called the "Street." As Hiro, the protagonist, puts on his VR goggles, he feels at home in the construct and leisurely walks the heavily crowded but simulated urban spaces. As on the streets of London in Poe's "The Man of the Crowd," the "Street" in Snow Crash is also the rallying place of 
the stranger, the character who observes, but here as if twice removed from what is being observed, shielded twice, first by the interiority of his location in real space, second by his mingling in the virtual crowd:

$[\mathrm{H}] \mathrm{e}$ can see all of the people in the front row of the crowd with perfect clarity [...] persons who are accessing the Metaverse through cheap public terminals, and who are rendered in jerky, grainy black and white. A lot of these are run-of-the-mill psycho fans [...] they can't even get close in Reality, so they goggle into the Metaverse to stalk their prey. (38)

The detective-as-stalker is also one of the main themes in Greg Bear's 1990 Queen of Angels, where LAPD police officer and detective, Mary Choy, is stalking the elusive psychopath killer Emanuel Goldsmith. In the course of her investigation, she has to go to the island of Hispaniola and is involved in another case. In the meantime, Goldsmith is found and two researchers enter his brain, inside what they call the "Country of the Mind," in a simulation to trace the source of Goldsmith's evil inclinations. Expectedly, the landscape visited is that of a city:

In their movement and bustle, the inhabitants had very little real individuality. Their images conveyed a blur of color, a flash of indistinct limb or clothing, an instant of expression like a hastily applied cutout from a photo gallery of faces. The effect was more than impressionistic; Martin and Carol truly felt themselves alone in this crowd. (357)

41 The researchers, simulated detectives of the mind, are once again facing the unknown and, as the story unfolds, fail to "read" the killer's mind. In fact, they end up being infected themselves, in tune with the original Poe-Benjamin dialectic of gazing.

It is, indeed, with cyberspace that the full potential of Poe's "The Man of the Crowd" was to be unleashed: after having traveled across the Atlantic and back, the new cyberdetective, in the guise of the cybernaut, can stalk the vast digital reaches as a true Deleuzian nomad. From behind a screen, the cyber-flâneur lurks among the other visible yet invisible cybernauts, safely ensconced behind an anonymity of person, class, position, and gender. ${ }^{4}$ As soon as the cybernaut logs in, he/she is instantly transported to a twilight region which is neither the interior nor the exterior, a region which, as in Poe's "The Man of the Crowd," is teeming with different people, nay, with different cultures, tongues, and traditions of bewildering and previously unheard-of variety. Cyberspace, as metropolis, what Mike Featherstone called a "data city" (911), vastly outnumbers any city on earth in diversity and range of experience, and cyber-flâneurs can choose to invisibly stalk-if they have the technological know-how-the digital polis or, on the contrary, to engage in the exchange of data or consumer goods. If what brought the original flâneur to his end was, according to Benjamin, Parisian motor traffic and if, as Susan Buck-Morss aptly said, today's would-be flâneurs, "like tigers or pre-industrial tribes," are indeed "cordoned off on reservations, preserved within the artificially created environments of pedestrian streets, parks, and underground passageways" (102), could virtual reality be the flâneur's ultimate revenge?

Yet is it really the case? Michael Dibdin, in his detective novel Blood Rain, has his protagonist's daughter discover, upon setting up a network for the special police, a "virtual draught," a "flaw in cyberspace, a seepage of information from the system," felt "almost physically," like a "malaise" (42). Later on, just before she is killed, her laptop displays the words: "FATAL ERROR MESSAGE! THIS COMPUTER HAS PERFORMED AN ILLEGAL OPERATION AND WILL BE SHUT DOWN" (148). Is cyberspace the culmination of The Man of the Crowd's transatlantic voyage and back, or is it still the 
same angst experienced by Poe which really comes from the inside and masquerades as otherwise? Is this virtual city the locus, once again, of that ever-present and also everincreasing danger of turning human flesh into what is worse that machines, into data bits?

Poe's legacy, particularly that of "The Man of the Crowd," is as strong and as relevant as ever. As the creator of the detective story, Poe was courageous enough to peer into the theoretical abyss which would be soon slowly building up after the demise of positivism at the end of the nineteenth century. Fortified by those other daring minds of the mid-twentieth century across the Atlantic, Poe's concept of the flâneurdetective-ontological quester went far beyond Dupin's initial apprehensions, and came back to occupy contemporary American fiction, ultimately providing twenty-firstcentury Homo Cyberneticus with the tools needed to deal with the bewildering changes ahead.

\section{BIBLIOGRAPHY}

Works Cited

Alford, Steven E. “Mirrors of Madness: Paul Auster's The New York Trilogy.” Critique 37.1 (Fall 1995): 17-33.

Ashley, Robert P. “Wilkie Collins and the Detective Story.” Nineteenth-Century Fiction 6.1 (Jun. 1951): 47-60.

Auster, Paul. Oracle Night. London: Faber and Faber, 2004.

---. The New York Trilogy. New York: Penguin, 1990.

Bandy, W. T. “Poe’s Secret Translator: Amédée Pichot.” MLN 79.3 (May 1964): 277-80.

Bear, Greg. Queen of Angels. London: Millennium, 2000.

Benjamin, Walter. The Arcades Project. Cambridge, MA: The Belknap Press of Harvard UP, 1999.

Briggs, Robert. "Wrong Numbers: The Endless Fiction of Auster and Deleuze and Guattari and ..." Critique 44.2 (Winter 2003): 213-24.

Buck-Morss, Susan. "The Flaneur, the Sandwichman and the Whore: The Politics of Loitering." New German Critique 39 (Autumn 1986): 99-140.

Cannon, JoAnn. “The Reader as Detective: Notes on Gadda's 'Pasticciaccio'.” Modern Language Studies 10.3 (Autumn 1980): 41-50.

Classic Text Adventure Masterpieces of Infocom, CD-ROM, Activision, Inc., 1996.

Cusset, François. French Theory: Foucault, Derrida, Deleuze \& Cie et les mutations de la vie intellectuelle aux États-Unis. Paris: La Découverte, 2003.

Darnall, F. M. “The Americanism of Edgar Allan Poe.” The English Journal 16.3 (Mar. 1927): 185-92. 
Deleuze, Gilles et Félix Guattari. Mille Plateaux: Capitalisme et Schizophrénie. Paris: Les Éditions de Minuit, 1980.

DeLillo, Don. Cosmopolis. London: Picador, 2004.

---. Mao II. London: Vintage, 1992.

Dibdin, Michael. Blood Rain. London: Faber \& Faber, 2000.

Doctorow, E. L. City of God. New York: Plume, 2001.

Elbert, Monika M. “'The Man of the Crowd' and the Man outside the Crowd: Poe's Narrator and the Democratic Reader.” Modern Language Studies 21.4 (Autumn 1991): 16-30.

Engel, Claire-Eliane. "L’État des travaux sur Edgar Allan Poe en France." Modern Philology 29.4 (May 1932): 482-88.

Featherstone, Mike. "The Flâneur, the City and Virtual Public Life." Urban Studies 35.5/6 (May 1998): 909-25.

Françon, Marcel. "Poe et Baudelaire.” PMLA 60.3 (Sep. 1945): 841-59.

Frank, Lawrence. “'The Murders in the Rue Morgue': Edgar Allan Poe's Evolutionary Reverie.” Nineteenth-Century Literature 50.2 (Sep. 1995): 168-88.

Gibson, William. Neuromancer. London: HarperCollins, 2001.

Goebel, Rolf J. "Benjamin's Flâneur in Japan: Urban Modernity and Conceptual Relocation.” The German Quarterly 71.4 (Autumn 1998): 377-91.

Grella, George. "Murder and Manners: The Formal Detective Novel." NOVEL: A Forum on Fiction 4.1 (Autumn 1970): 30-48.

Grimstad, Paul C. "Algorithm-Genre-Linguisterie: 'Creative Distortion' in Count Zero and Nova Express." Journal of Modern Literature 27.4 (Summer 2004): 82-92.

Hantke, Steffen. "Difference Engines and other Infernal Devices: History According to Steampunk." Extrapolation 40.3 (Fall 1999): 244-54.

Haslam, Jason. "Coded Discourse: Romancing the (Electronic) Shadow in The Matrix1." College Literature 32.3 (Summer 2005): 92-115.

Holquist, Michael. "Whodunit and Other Questions: Metaphysical Detective Stories in Post-War Fiction." New Literary History 3.1 (Autumn 1971): 135-56.

Hutcherson, Dudley R. “Poe’s Reputation in England and America, 1850-1909.” American Literature 14.3 (Nov. 1942): 211-33.

Kennedy, Gerald J. “The Limits of Reason: Poe’s Deluded Detectives.” American Literature 47.2 (May 1975): 184-96.

Kupsch, Kenneth. “Finding V.” Twentieth Century Literature 44.4 (Winter 1998): 428-46.

Lawler, James. "Daemons of the Intellect: The Symbolists and Poe." Critical Inquiry 14.1 (Autumn 1987): 95-110.

Little, William G. "Nothing to go on: Paul Auster's City of Glass." Contemporary Literature 38.1 (Spring 1997): 133-61.

Malmgren, Carl D. “The Crime of the Sign: Dashiell Hammett's Detective Fiction.” Twentieth Century Literature 45.3 (Autumn 1999): 371-84. 
Matthew, John. “Poe's Indebtedness to French Literature.” The French Review 9.3 (Feb. 1936): 217-23.

Niesz, Anthony J., and Norman Holland. “Interactive Fiction.” Critical Inquiry 11.1 (Sep. 1984): 110-29.

Philips, Edith. “The French of Edgar Allan Poe.” American Speech 2.6 (Mar. 1927): 270-74.

Poe, Edgar Allan. Selected Writings. London: Penguin, 1979.

Punday, Daniel. "Lines of Flight: Discursive Time and Countercultural Desire in the Work of Thomas Pynchon." Studies in the Novel 37.1 (Spring 2005): 109-11.

Pynchon, Thomas. The Crying of Lot 49. London: Vintage, 2000.

---. V. London: Vintage, 2000.

Riddel, Joseph N. “The ‘Crypt' of Edgar Poe.” Boundary 27.3 (Spring 1979): 117-44.

Schama, Simon. “New York, Gaslight Necropolis.” The New York Times, June 19, 1994.

Schmiedgen, Peter. "Abraham and the Flaneur: Levinas, Benjamin, and Urban Life.” Philosophy Today 49.1 (Spring 2005): 46-54.

Schroeder, Randy. "Inheriting Chaos: Burroughs, Pynchon, Sterling, Rucker." Extrapolation 43.1 (Spring 2002): 89-97.

Shulman, Robert. "The Artist in the Slammer: Hawthorne, Melville, Poe and the Prison of their Times." Modern Language Studies 14.1 (Winter 1984): 79-88.

Spanos, William V. "The Detective and the Boundary: Some Notes on the Postmodern Literary Imagination." Boundary 21.1 (Autumn 1972): 147-68.

Stephenson, Neal. Snow Crash. London: Penguin, 1993.

Virtanen, Reino. “Allusions to Poe’s Poetic Theory in Valéry's 'Cahiers'.” The Bulletin of the Midwest Modern Language Association 2.1 (1969): 113-20.

Werner, James V. "The Detective Gaze: Edgar A. Poe, the Flaneur, and the Physiognomy of Crime." American Transcendental Quarterly 15.1 (Mar. 2001): 5-21.

Zilcosky, John. "The Revenge of the Author: Paul Auster's Challenge to Theory." Critique 39.3 (Spring 1998): 195-206.

Zimmermann, Eleonore M. "Mallarmé et Poe: Précisions et Aperçus." Comparative Literature 6.4 (Autumn 1954): 304-15.

\section{NOTES}

1. All references to Poe will be indicated by " $P$ " followed by the page number.

2. Works in French have been translated by me.

3. Edgar Lawrence Doctorow's father, a fervent admirer of Poe, named his son after him (Schama).

4. Within a decade, most of what had been advanced by theoreticians of post-structuralism like Barthes, Derrida, Deleuze, Baudrillard, and others, was being uncannily translated onto the silicon chip and later, given the unprecedented development in computer power, onto the Internet. One 
of the first experiments involving the digital reader-as-detective was interactive fiction (IF), also known as text-based adventures. Willie Crowther's pioneering game, simply called "Adventure," was soon followed by more sophisticated IF games, many of them, interestingly, of the detective type, like Infocom's "Deadline," (subtitled "A locked door. A dead man. And 12 hours to solve the murder") (1981) "The Witness," (1983) “Suspect," (1984) “Moonmist," (1986) and "Sherlock: The Riddle of the Crown Jewels," (1988) all complete with manuals, blueprints, transcripts, and other familiar detective paraphernalia. IF kept the classical ingredients of the detective story, but added the player as detective with unparalleled freedom of choice and action. For more on this interaction and the empowerment of the reader/player becoming a digital flâneur, see Anthony J. Niesz and Norman N. Holland, as well as their parallels between Pynchon's stories-within-stories and the immersive capabilities of these "new technologies."

\section{INDEX}

Keywords: Postmodernism, Don DeLillo, Thomas Pynchon, Crowd, detective, flâneur, cybernaut, contemporary fiction, nomad, city, Edgar Allan Poe, Paul Auster, Greg Bear, Walter Benjamin, Gilles Deleuze, Michael Dibdin, E. L. Doctorow, William Gibson, Félix Guattari, Neal Stephenson.

\section{AUTHOR}

PAUL JAHSHAN

Associate Professor of American Studies, Notre Dame University, Zouk, Lebanon 